Catalyst Papers in Press are peer-reviewed, accepted articles that have not yet been edited or formatted, but may be cited by DOI. The final version may contain substantive or nonsubstantive changes.

doi: 10.5344/catalyst.2021.21007

ASEV CATALYST REPORT

\title{
Performance of Early Fruit-Zone Leaf Removal in Cabernet Sauvignon and Merlot in an Arid Climate
}

\author{
Michelle M. Moyer, ${ }^{1 *}$ Jensena M. Newhouse, ${ }^{2}$ and Maria S. Mireles ${ }^{1}$
}

${ }^{1}$ Department of Horticulture, Washington State University Irrigated Agriculture Research and Extension Center, Prosser, WA 99350; and ${ }^{2}$ Formerly Department of Horticulture, Washington

State University Irrigated Agriculture Research and Extension Center, Prosser, WA 99350.

*Corresponding author (michelle.moyer@wsu.edu)

Acknowledgments: The authors would like to thank the Washington State Grape and Wine Research Program and USDA Hatch Accession \#0226789 for providing funding or in-kind laboratory assessments for this project. The authors would also like to especially thank ETS Laboratories for the methoxypyrazine (IBMP) testing. Additional thanks goes to Devon Newhouse of Newhouse Farms of Sunnyside, WA, for the use of the vineyard, and Eric Gale, Ashley Boron, Steve Hoff, Margaret McCoy, Katherine East, Elise Mills, Alexa McDaniel, and Bernadette Gagnier for their technical assistance.

Manuscript submitted Sept 13, 2021, revised Oct 15, 2021, accepted Oct 22, 2021

This is an open access article distributed under the CC BY license (https://creativecommons.org/ licenses/by/4.0/).

By downloading and/or receiving this article, you agree to the Disclaimer of Warranties and Liability. The full statement of the Disclaimers is available at https://www.asevcatalyst.org/content/proprietary-rights-notice-catalyst. If you do not agree to the Disclaimers, do not download and/or accept this article.

Goals: Our goals were to evaluate how the timing of early fruit zone leaf removal, done between prebloom and post-fruit set, influenced the risk of reduced fruit set, sunburn, and fruit quality in Vitis vinifera Cabernet Sauvignon and Merlot grown in the hot, arid, and irrigated region of eastern Washington State. 
Catalyst Papers in Press are peer-reviewed, accepted articles that have not yet been edited or formatted, but may be cited by DOI. The final version may contain substantive or nonsubstantive changes.

Key Findings:

- Fruit set was reduced in Vitis vinifera Cabernet Sauvignon when fruit-zone leaf removal was completed during bloom. Prebloom and postbloom fruit-zone leaf removal did not reduce fruit set.

- Sunburn occurred on fruit on the westside of the canopy in both $V$. vinifera Cabernet Sauvignon and Merlot. Sunburn severity increased with later-timed fruit-zone leaf removal. Overall, the maximum severity of sunburn was $15 \%$ of the cluster surface area. This emphasizes the need to make canopy management decisions that are informed by weather forecasts, to achieve desired management goals.

Impact and Significance: Early fruit-zone leaf removal was traditionally avoided in eastern Washington, in favor of completing the practice after berries have reached pea-size. The later timing of leaf removal, however, can result in sudden exposure of the fruit during the typically warmest and sunniest time of the growing season. Results from this study show that many of the assumed risks associated with early fruit-zone leaf removal, such as extreme reduction in fruit set and sunburn, are not fully realized. This means that early fruit-zone leaf removal could be - Vintage had adopted in this hot, arid climate without a high risk of reduction in fruit quantity or quality. 
Catalyst Papers in Press are peer-reviewed, accepted articles that have not yet been edited or formatted, but may be cited by DOI. The final version may contain substantive or nonsubstantive changes.

doi: 10.5344/catalyst.2021.21007

\section{Overview}

Canopy management in commercial vineyards is a practice that comes in many forms, with a variety of desired outcomes based on the production system. From more permanent approaches such as the choice of training systems, to more variable in-season approaches such as shoot manipulation or fruit-zone leaf removal, the intended result of canopy manipulation typically focuses on altering the canopy microclimate to influence either current year fruit quality and quantity, or subsequent season fruit quantity. $1,2,3,4,5,6,7$

Fruit-zone leaf removal, through its alteration of canopy architecture, can influence the canopy microclimate to where it reduces the favorability for disease development, particularly for powdery mildew (Erysiphe necator) and Botrytis bunch rot (Botrytis cinerea). ${ }^{8,9,10}$ Historically performed near véraison, this technique removes leaves around clusters to improve sun exposure and increase air flow. Recent studies have focused on fruit-zone leaf removal earlier in the growing season (i.e., pre-bunch closure). The intent is that the earlier timing may reduce the risk of sunburn, reduce cluster compactness, and potentially improve pest and disease management programs by improving spray penetrations during key periods of fruit development. ${ }^{4,7,11,12,13,14,15,16}$ Fruit-zone leaf removal earlier than véraison can also help to reduce under-ripe flavors in red wine varieties (i.e., reduction of methoxypyrazines) ${ }^{6}$, and enhance anthocyanin production during cool vintages. ${ }^{17}$ These latter attributes related to alterations in fruit quality may be of greater importance to growers in arid climates, where disease pressure is often low and not the primary driver for the

adoption of cultural practices in wine grape vineyards. ${ }^{18}$ 
Catalyst Papers in Press are peer-reviewed, accepted articles that have not yet been edited or formatted, but may be cited by DOI. The final version may contain substantive or nonsubstantive changes.

doi: 10.5344/catalyst.2021.21007

72

73

80

Our past research has shown that early fruit-zone leaf removal is a viable option in white wine grapes in the warm arid conditions of eastern Washington State. ${ }^{13}$ Still, the practice of early, complete fruit-zone leaf removal has not been widely adopted, likely driven by lack of mechanization ability. There are also perceived concerns related to increased sunburn, and reduction in both fruit quantity (fruit set) and quality when applied to wine grapes grown in a climate with notable hot and dry growing seasons. The project presented here was designed as a 3-yr demonstration trial to highlight how early fruit-zone leaf removal may influence yield and quality on two key red wine grape (Vitis vinifera) varieties in the region.

(1)

\section{Major Observations and Interpretations}

Weather description. The 2014 vintage was considered a slightly warmer-than-average and dry for the region, with a season total heat accumulation of 2027 GDD, and precipitation of 82.3 mm, with $54.4 \mathrm{~mm}$ falling between 1 Apr and 31 Oct (Fig. 1A). The following vintage, 2015, was also considered warmer and dryer than average, with drier and warmer vintage relative to the average, with a season total degree day accumulation of 2141 GDD, and the total annual precipitation of $141.7 \mathrm{~mm}$, with $41.7 \mathrm{~mm}$ falling between 1 Apr and 31 Oct (Fig. 1B). There was a notable rain event in mid-May, and no measurable precipitation in June, July or August. The 2016 vintage had a near-average heat accumulation for the area, with slightly higher-thanaverage in-season precipitation. The season total degree day accumulation was 1859 GDD, with a total annual precipitation of $200.6 \mathrm{~mm}$, with $119.1 \mathrm{~mm}$ falling between 1 Apr and 31 Oct (Fig. 
Catalyst Papers in Press are peer-reviewed, accepted articles that have not yet been edited or formatted, but may be cited by DOI. The final version may contain substantive or nonsubstantive changes.

doi: 10.5344/catalyst.2021.21007

92 1C). There was measurable precipitation in June and July, which is uncharacteristic for the

93 region, and notable precipitation events in October.

Total leaf area removed during different times, and influence of leaf removal timing on dormant

pruning weights. In other studies, early fruit zone leaf removal typically removed $20 \%$ to $39 \%$ of

97 total canopy leaf area. ${ }^{19,20}$ In our study, total area removed was higher (Fig. 2), likely due to the

overall smaller canopies maintained by Washington growers relative to general canopy sizes in

other production regions. In Cabernet Sauvignon, leaf removal at prebloom removed

100

approximately $50.5 \%$ and $48.9 \%$, of the foliage in 2015 and 2016, respectively (Fig. 2A). In

101

Merlot, leaf removal at prebloom in 2015 removed approximately $70.9 \%$ of the foliage, whereas

102

in 2016 only $37.3 \%$ was removed (Fig. 2B). Less than $40 \%$ of the total leaf area was removed for

103

all remaining leaf removal timings in both varieties in both years. Total leaf area removed was not measured in 2014.

Influence of vintage and leaf removal treatments of fruit set, berry size, and cluster weights. A common concern relating to the adoption of early fruit-zone leaf removal is the potential impact it may have on yield. These impacts can come in a variety of forms but are usually related to a reduction in fruit set or number of berries per cluster. But these impacts on yield are variable and often inconsistent, driven by specific combinations of leaf removal timing and severity,

111 environmental conditions, management approaches, and variations in variety response. ${ }^{4,15,19,21,22}$ 
Catalyst Papers in Press are peer-reviewed, accepted articles that have not yet been edited or formatted, but may be cited by DOI. The final version may contain substantive or nonsubstantive changes.

doi: 10.5344/catalyst.2021.21007

112 In other words, a reduction in fruit set as a result of early fruit-zone leaf removal is not a

113 universal response and needs to be regionally considered.

115 In this trial, fruit set in Cabernet Sauvignon was influenced by both vintage and timing of leaf

116 removal (but no interactive effects) (Table 1). Both 2014 and 2015 were very low fruit set

117 vintages. Leaf removal at bloom resulted in a reduction in fruit set relative to no leaf removal

118 (control), postbloom leaf removal, or mechanical leaf removal. Leaf removal at prebloom did not 119 reduce fruit set relative to the control or postbloom timings, but fruit set was reduced relative to 120 mechanical leaf removal. A similar response was seen for berry diameter; the 2014 and 2015

121 vintages had smaller berries, and the smallest diameter berries were associated with leaf removal

122 at bloom. Berry and cluster weights in Cabernet Sauvignon were influenced by the interactive

123 effect of vintage and leaf removal timing. For example, while the 2016 vintage had heavier

124 berries and clusters, leaf removal at bloom reduced these weights, and this reduction in weight

125 was exacerbated during the warmer 2014 and 2015 vintages. These interactive effects indicate

126 that when available, current and forecast weather conditions should be considered before the

127 application of fruit-zone leaf removal, as conducting the practice during an extreme weather

128 event such as heat may reduce certain yield parameters when performed during warmer-than-

129 average vintages.

131 Fruit set in Merlot was not impacted by vintage or timing of leaf removal, but both factors did 132 influence berry and cluster size. In 2015, berries and clusters were smaller than they were in 
Catalyst Papers in Press are peer-reviewed, accepted articles that have not yet been edited or formatted, but may be cited by DOI. The final version may contain substantive or nonsubstantive changes.

doi: 10.5344/catalyst.2021.21007

other years. Leaf removal at bloom in Merlot resulted in lighter berries when compared to the mechanical leaf removal treatment, but those same berries were not statistically lighter than the non-leaf removed control or other manual leaf removal timings. Merlot's consistency in yield component response (fruit set, berry size, cluster size) to the different timings of leaf removal, make it a good candidate for this practice.

Influence of vintage and leaf removal timing on sunburn, fruit juice metrics, and skin phenolics.

Sunburn on fruit in Cabernet Sauvignon was influenced by the interaction of vintage and the side of the canopy on which fruit sunburn ratings were taken $(\mathrm{P}=0.001)$. Sunburn was also influenced by the interaction between the timing of leaf removal and the side of the canopy on which fruit sunburn ratings were taken $(P=0.004$; Fig. 3A). In both 2015 and 2016, fruit on the western side of the vine had a higher average severity of sunburn than fruit on the eastern side of the vine (12.2\% and 7.5\% severity for 2015 -West and 2016 -West, respectively versus $0.6 \%$ and 0.5\% for 2015-East and 2016-East, respectively). However, in 2014, there was no difference in sunburn between fruit on either side of the vine (5.9\% and $2.0 \%$ for 2014 -West and 2014-East, respectively); this may likely be attributed to slightly larger canopies in the block in 2014 relative to the size canopies were managed to in 2015 and 2016 (data not shown). Figure $3 \mathrm{~A}$ shows the interactive effect with timing of leaf removal and the side of the canopy sunburn was seen. Generally, sunburn was more severe for fruit on the western sides of the canopy, and the later the timing of leaf removal the higher the severity of sunburn. There was no interactive 
Catalyst Papers in Press are peer-reviewed, accepted articles that have not yet been edited or formatted, but may be cited by DOI. The final version may contain substantive or nonsubstantive changes.

doi: 10.5344/catalyst.2021.21007

153

154 155

effect of vintage and timing of leaf removal $(\mathrm{P}=0.44)$, and there was no three-way interaction between vintage, leaf removal timing, or the side of the canopy fruit were rated from $(\mathrm{P}=0.61)$.

\section{Sunburn in Merlot was only influenced by the interactive effects of timing of leaf removal and}

the side the canopy that cluster ratings were taken from $(\mathrm{P}=0.0005)($ Fig. 3B) and was not influenced by vintage $(\mathrm{P}=0.15)$. As with Cabernet Sauvignon, Merlot fruit on the western side of the vines had the higher average sunburn severity ratings, and the later timing of leaf removal exacerbated sunburn severity (Fig. 3B).

Differences in titratable acidity, methoxypyrazine (IBMP) and berry anthocyanin content in Cabernet Sauvignon (Table 2) were mostly driven by vintage, rather than by timing of leaf removal. This was also seen in Merlot (Table 3). The warmer years $(2014,2015)$ typically had lower titratable acidity, lower $\mathrm{pH}$, and higher berry anthocyanins in both varieties. In Cabernet Sauvignon, these warmer vintages also had reduced methoxyprazines (Table 2). Interestingly, in Cabernet Sauvignon, we saw lower skin tannins and phenolics in 2014 compared to 2016 (Table 2), but the opposite was true of Merlot for those two vintages (Table 3).

The timing of leaf removal influenced total soluble solids and skin phenolics in Cabernet Sauvignon; leaf removal at bloom resulted in higher total soluble solids than postbloom mechanical leaf removal, and also had higher skin phenolics than all other leaf removal timings.

173 No leaf removal in Cabernet Sauvignon resulted in fruit with lower skin tannins compared to 
Catalyst Papers in Press are peer-reviewed, accepted articles that have not yet been edited or formatted, but may be cited by DOI. The final version may contain substantive or nonsubstantive changes.

doi: 10.5344/catalyst.2021.21007

174 fruit from vines that underwent leaf removal at bloom or later. There was an interactive effect of

175 vintage and timing of leaf removal on final fruit $\mathrm{pH}$, but this was predominately driven by

176

177

178

179

180

181

182

183

184

185

186

187

188

189

190

191

192

193

194 vintage (higher $\mathrm{pH}$ in 2014), with a subtle influence of very low $\mathrm{pH}$ in 2015 as a result from bloom leaf removal. In Merlot, fruit-zone leaf removal only influenced titratable acidity, where fruit from the postbloom leaf removal timing was lower in titratable acidity than fruit from vines that received leaf removal at prebloom.

These predominately vintage-driven responses in both varieties emphasize the much larger role of annual weather patterns on these basic fruit quality metrics in an arid climate like eastern Washington, compared to the minor impacts that practices such as fruit-zone leaf removal may impart. Coupled with the yield response in the trial, this emphasizes the need to make weather (forecast)-informed vineyard management practice decisions, rather than simply applying practices such as fruit-zone leaf removal based on a traditional calendar schedule. If potentially detrimental weather events are predicted, management practices should be adjusted accordingly.

Influence of leaf removal timing on dormant pruning weights. In both 2014 and 2016, the timing of leaf removal did not influence dormant pruning weights (Fig. 4) in either variety (Cabernet Sauvignon, $\mathrm{P}=0.12$ and 0.56 respectively for 2014 and 2016; Merlot, $\mathrm{P}=0.67$ for both 2014 and 2016). In general, dormant pruning weights were less in 2014 than they were in 2016 (Fig. 4). Pruning weights were not collected in 2015. For general context, average pruning weights (across all treatments) per linear meter of vine for Cabernet Sauvignon was $0.26 \mathrm{~kg} / \mathrm{m}$ in 2014 
Catalyst Papers in Press are peer-reviewed, accepted articles that have not yet been edited or formatted, but may be cited by DOI. The final version may contain substantive or nonsubstantive changes.

doi: 10.5344/catalyst.2021.21007

214 equal.

and $0.38 \mathrm{~kg} / \mathrm{m}$ in 2016. For Merlot, they were $0.16 \mathrm{~kg} / \mathrm{m}$ in 2014 and $0.31 \mathrm{~kg} / \mathrm{m}$ in 2016 .

Typically suggested optimal values are between 0.3 and $0.6 \mathrm{~kg} / \mathrm{m}^{23}$, indicating the vines in this study had lower vegetative growth than typically desired. Given the use of deficit irrigation to control canopy size (and cane diameter) in this production system, these lower-than-optimal values are not surprising, as these index numbers were not developed using data from vineyards that practice controlled deficit irrigation.

\section{Broader Impact}

Early fruit zone leaf removal does not need to be considered as a cultural approach that can, or should, be applied across all managed acreage. Rather, it can be a tool that is deployed under specific situations to achieve a desired goal or set of goals. Those goals can range from alterations in attributes related to fruit quality (total soluble solids, titratable acidity, color, and/or tannins), to aiding disease management approaches. As with many practices, the adoption of early fruit zone leaf removal needs to be placed into environmental context, both on the longterm (climate) and short term (vintage) scale. In the study presented here, there were minimal overall negative impacts of early fruit-zone leaf removal; however, leaf removal at bloom did result in reduced fruit set and berry size and increase skin tannins and phenolics in in Cabernet Sauvignon. This highlights that when describing "early" in the concept of early fruit-zone leaf removal, specific phenological stages should be mentioned, as not all early timings are created 
Catalyst Papers in Press are peer-reviewed, accepted articles that have not yet been edited or formatted, but may be cited by DOI. The final version may contain substantive or nonsubstantive changes.

doi: 10.5344/catalyst.2021.21007

When considering the environmental risks of fruit-zone leaf removal (whether early or late season) in a hot, arid climate like eastern Washington, the fear of sunburn on fruit is a driving factor for lack of application of the practice. This is understood, as sunburn is generally the result of both high temperatures, and high sunlight exposure. ${ }^{24}$ However, in a climate like eastern Washington, extreme heat events typically do not occur until mid-growing season (e.g., July), well after grapevine bloom for most varieties in the region. Thus, completing fruit-zone leaf removal earlier in the growing season when the risk of extreme heat is low, is the probable reason we saw a reduction in sunburn in those treatments (Fig. 3). Shifting to earlier leaf removal likely also allows the developing fruit to potentially stave off severe sunburn through the accumulation of carotenoids and phenolic compounds. ${ }^{24}$ In irrigated environments, viticulturists might be able to further reduce the risk of sunburn by adjusting their irrigation practices during heatwaves that occur post-leaf removal; water stress through a reduction in transpiration can increase the risk of sunburn through increasing plant surface temperatures in direct sunlight. A practice such as early fruit-zone leaf removal can likely be adopted in most climates, provided the practicing grower understands the abiotic factors that can influence its success. Growers should recognize that while their climate might be conducive for such a practice, specific weather patterns within the growing season (e.g. forecast heat waves) may require a shift in practice timing, degree of severity (i.e., total leaves removed), or follow-up mitigation strategies such as adjustment to irrigation, to avoid plant damage. 
Catalyst Papers in Press are peer-reviewed, accepted articles that have not yet been edited or formatted, but may be cited by DOI. The final version may contain substantive or nonsubstantive changes.

The mechanization of leaf removal has predominately been done by machines that remove leaves by pulling them into cutting / shredding mechanisms. This approach is indiscriminate and works based on weight differences between leaves and ripening fruit; heavier fruit is less likely to be sucked into the blades than foliage. With the ease of mechanization of later leaf removal, the concept of returning to manual labor to perform early-season leaf removal results in a focus on the economics of manual labor, ${ }^{25}$ especially in a tight labor market. Fortunately, newer leaf removal technologies, which remove leaves by pulsing high velocity air towards the canopy, have shown potential in mechanizing early fruit-zone leaf removal. ${ }^{7}$ It is important to place the discussion of economics and labor into context. While mechanization may be a favored goal for large vineyard operations that struggle to maintain profitable business ventures in a challenging labor climate, it is not the primary goal for all grape growers. Particularly for smaller vineyard operations where the purchase of such mechanization equipment is not feasible, the integration of manual early fruitzone leaf removal may be a practice that is worth considering to complement other fruit production goals. This might also hold true for those that have contractual obligations for non-mechanized activities in the vineyard,

The results of this 3-yr demonstration trial show that early fruit-zone leaf removal, have a place in warm, arid climates with limited negative impacts on fruit quality, and only minor impacts on yield components. This information may prompt growers who are not currently practicing fruit-zone leaf removal to try it in their vineyards if they are struggling with canopy-environment related challenges (low fruit coloration, high disease pressure), or shift their practice to earlier in the 
Catalyst Papers in Press are peer-reviewed, accepted articles that have not yet been edited or formatted, but may be cited by DOI. The final version may contain substantive or nonsubstantive changes.

doi: 10.5344/catalyst.2021.21007

257

258

259

260

261

262

263

264

265

266

267

268

269

270

271

272

273

growing season if they have experienced problems (i.e., sunburn) when conducting fruit-zone leaf removal later in the growing season.

\section{Experimental Design}

Vineyard description. This trial was conducted in a commercial vineyard located west of Sunnyside, Washington USA ( $\left.46^{\circ} 18^{\prime} 53^{\prime} \mathrm{N}, 120^{\circ} 6^{\prime} 54^{\prime} \mathrm{W}\right)$ from spring 2014 to early winter 2016 , for a total of three vintages. The soil at the site is a course-silty, mixed, superactive mesic Xeric Haplocambids (pedon: Wardon silt loam), with a 15 to $30 \%$ slope as described on the USDA-NRCS Website (https://soilseries.sc.egov.usda.gov/osdname.aspx). One block each of Vitis vinifera Cabernet Sauvignon, field grafted onto a $V$. vinifera Syrah rootstock, and $V$. vinifera Merlot on own root were used. Merlot and the Syrah rootstock were planted in 1999; Syrah was grafted-over to Cabernet Sauvignon in 2011. Rows are on a north-south orientation. Plant spacing were $2.7 \mathrm{~m}$ (between rows) x $1.8 \mathrm{~m}$ (between vines) in both vineyard blocks. Vines re trained to bilateral cordons, and annually pruned to two-bud spurs. Canopies were trained to a modified vertical shoot positioning with only a single, centered catchwire at approximately $40 \mathrm{~cm}$ above the fruiting wire. Irrigation was drip applied. In all years, water was applied by the

274 irrigation was applied on biweekly irrigation sets to a regulated deficit of $80 \% \mathrm{ET}_{\mathrm{o}}$. A final

275 irrigation set was applied in October each year, prior to the termination of irrigation supply, to

276 replenish the soil moisture profile. All other management practices (e.g., insect pest, disease, 277 nutrient) were carried out per the cooperating grower's standard production practices. 
Catalyst Papers in Press are peer-reviewed, accepted articles that have not yet been edited or formatted, but may be cited by DOI. The final version may contain substantive or nonsubstantive changes.

doi: 10.5344/catalyst.2021.21007

278

279

280

281

282

283

284

285

286

287

288

289

290

291

292

293

294

295

296

297

298

Weather data. Weather data was collected using Washington State University's AgWeatherNet system (http://weather.wsu.edu). The "Snipes Mountain" weather station was used, located 3.3 $\mathrm{km}$ due east from the research site. Average daytime high and low temperatures and total precipitation data were recorded at these stations, and growing degree days (base of $10^{\circ} \mathrm{C} ; 1$ April to 31 October) and evapotranspiration $\left(\mathrm{ET}_{\mathrm{o}}\right)$ were calculated as described on the AgWeatherNet site. For 2014, weather data was only available starting on 27 Mar 2014, the date the station was installed.

\section{Leaf removal timing and approach. Leaf removal was done either manually, or mechanically} using a Binger Seilzug Leaf Remover EB 490 (Binger Seilzug, Bingen, Germany). For manual leaf removal, all leaves and lateral shoots from the base of each count shoot up to the secondary cluster were removed on both sides of the canopy. Mechanical leaf removal was on the east side of the vine canopy only per manufacturer's instructions; this side-limitation is due to the high temperatures common at the site and the general later-timing of mechanical leaf removal. The different timing of leaf removal evaluated in this study were: (i) prebloom (rachis elongation) hand leaf removal, (ii) full bloom (50\% of clusters at 50\% capfall) hand leaf removal, (iii) approximately 4 weeks postbloom hand leaf removal, (iv) grower-timed postbloom mechanical leaf removal, and (vi) no fruit zone leaf removal. The timing of the postbloom hand leaf removal was adjusted to accommodate for labor-limiting temperature spikes, which are also conditions that are commonly associated with sunburn. These same avoidances are also generally considered by grower-producers in the area (i.e., limiting employee activities and canopy 
Catalyst Papers in Press are peer-reviewed, accepted articles that have not yet been edited or formatted, but may be cited by DOI. The final version may contain substantive or nonsubstantive changes.

doi: 10.5344/catalyst.2021.21007

management activities when temperatures daily high temperatures exceed $35^{\circ} \mathrm{C}$ ). The timing of the mechanical leaf removal ("industry control"), was not determined based on vine phenology, but rather, followed the typical application schedule the cooperating grower usually uses for this practice, as it aligns with other on-farm activities. As a result, while the date of the mechanical leaf removal was similar between years, the phenological stage of the vine at the time of application was not. A summary of the dates at which leaf removal occurred across all three years is presented in Table 4.

The different timings of leaf removal (i.e., "treatments") were replicated four times in a randomized block design. Each treatment was applied to 30 vines in each replicate (10 vines per row, across 3 adjacent rows). The six center vines in the center row of each treatment replicate were used for data collection and observation, allowing a 1-row buffer on either side of the treatment, and a 2-vine buffer on either end of the observed vines in the center row. The same treatments were imposed on the same vines in all three years of the study.

Fruit set, berry size, and cluster weights. Fruit set was calculated for 12 clusters per treatment replicate, using the technique described by Komm and Moyer (2015). ${ }^{13}$ In this technique, calyptra lost during the bloom period are collected in a fine mesh bag affixed to the inflorescence, and the total number of calyptra captured per cluster are compared to the total number of berries per cluster (for that same cluster) destructively counted at the start of véraison. 
Catalyst Papers in Press are peer-reviewed, accepted articles that have not yet been edited or formatted, but may be cited by DOI. The final version may contain substantive or nonsubstantive changes.

doi: 10.5344/catalyst.2021.21007

To determine cluster weight and berry size, additional clusters were collected near harvest:

Cabernet Sauvignon, 21 Sept 2014, 27 Aug 2015, and 29 August 2016; Merlot, 15 Sept 2014, 19 Aug 2015, and 23 Aug 2016. Three clusters per treatment replicated were harvested, weighed, and then 20 individual berries per cluster were removed (60 berries per treatment replicate).

Thirty of these berries measured using a digital caliper (Electronic Digital Caliper \#CO 030150, Marathon Watch Company, Richmond Hill, ON, Canada) to assess berry diameter and then reserved for Brix, TA and $\mathrm{pH}$ measurements (described below). The remaining 30 berries per treatment replicate (with pedicels intact) were then were reserved for phenolic analysis, as described below.

Fruit juice metrics, phenolics, methoxypyrazines, and sunburn. The 30 berries per treatment replicate that were reserved for Brix, TA and $\mathrm{pH}$ measurements were crushed, and the resulting juice was used. Juice soluble solids were measured using a digital refractometer (Quick-Brix 60, Mettler-Toledo@, Schwerzenbach, Switzerland). Juice $\mathrm{pH}$ was measured using an electrode (InLab® Versatile 413, Mettler-Toledo@, Schwerzenbach, Switzerland). Juice TA was measured and calculated as described by Iland et al. (2000). ${ }^{26}$

Berries reserved for skin phenolic analysis were processed as described by Komm and Moyer (2015). ${ }^{13}$ Tannin, phenolic, and anthocyanin measurements were done using protocols developed by Hagerman and Butler $(1978)^{27}$ and Harbertson et al. (2003). ${ }^{28}$ IBMP (3-isobutyl-2methoxyprazine) was evaluated by randomly collecting 100 berries per treatment replicate, juicing 
Catalyst Papers in Press are peer-reviewed, accepted articles that have not yet been edited or formatted, but may be cited by DOI. The final version may contain substantive or nonsubstantive changes.

doi: 10.5344/catalyst.2021.21007

berries, and sending juice samples to ETS Laboratories (St. Helena, CA, USA) for analysis using their IBMP protocols. For Cabernet Sauvignon, berries were collected on 5 Sept 2014, 12 August 2015, and 21 August 2016. For Merlot, berries were sampled on 21 Aug 2014, 31 July 2015, and 21 Aug 2016.

Sunburn was rated as percent cluster surface area displaying sunburn symptoms. Symptoms were rated on five clusters per treatment replicate per side (east or west) of the canopy. In 2014, sunburn was rated in both varieties on 18 Aug. In 2015, sunburn was rated on 19 and 25 Aug in Merlot and Cabernet Sauvignon, respectively, and in 2016, sunburn was rated on 22 and 29 Aug in Merlot and Cabernet Sauvignon, respectively.

Total leaf area removed and dormant pruning weights. Total leaf area removed was estimated by collecting 12 shoots per treatment replicate (per variety) from buffer vines directly next to data collection vines. These shoots were immediately collected after each specific leaf removal treatment timing and brought back to the lab to measure leaf area (Li-COR Area Meter model 3100, Lincoln, NE, USA). Total leaf area per leaf on each shoot was measured; these were summed to estimate total leaf area per vine. To calculate leaf area removed, the area of the leaves located within the section of the shoot that would have experienced leaf removal, was subtracted from the total leaf area for that shoot. Total leaf area removed was not estimated in 2014 . 
Catalyst Papers in Press are peer-reviewed, accepted articles that have not yet been edited or formatted, but may be cited by DOI. The final version may contain substantive or nonsubstantive changes.

doi: 10.5344/catalyst.2021.21007

In both varieties, average dormant pruning weights were collected from five vines per leaf removal treatment replicate. Vines were pruned to two-bud spurs. Pruning weights were not collected in 2015 due to cooperating vineyard pruning prior to scheduled research pruning date. Dormant pruning weights from the 2014 growing season were collected on 4 Mar 2015. Dormant pruning weights from the 2016 growing season were collected on 20 Dec 2016.

Statistical analysis. The standard least squares model platform in JMP (version 14.0.0, SAS Institute Inc., Cary, NC) was used with year, treatment and year*treatment interaction as fixed effects and block as a random effect. Where significant differences were found, mean separation was performed using Tukey's HSD test.

\section{References and Endnotes}

1. Bledsoe AM, Kliewer WM and Marios JJ. 1988. Effets of timing and severity of leaf removal on yield and fruit composition of Sauvignon blanc grapevines. Am J Enol Vitic 39: 49-54.

2. Diago MP, Vilanova M and Tardaguila J. 2010. Effects of timing of manual and mechanical early defoliation on the aroma of Vitis vinifera L. Tempranillo wine. Am J Enol Vitic 61: 382-391

3. Dry PR. 2000. Canopy management for fruitfulness. Aus J Grape Wine Res 6: 109-115.

4. Palliotti A, Gardi T, Berrios JG, Civardi S and Poni S. 2012. Early source limitation as a tool for yield control and wine quality improvement in a high-yield red Vitis vinifera L. cultivar. Sci Hort 145:10-16.

5. Peterson JR and Smart RE. 1975. Foliage removal effects on 'Shiraz' grapevines. Am J Enol Vitic 26: 119-124.

6. Scheiner JJ, Sacks GL, Pan B, Ennahli S, Tarlton L, Wise A, Lerch SD and Vanden Huevel JE. 2010. Impact of severity and timing of basal leaf removal on 3-isobutyl-3-methoxypyrazine concentrations in red winegrapes. Am J Enol Vitic 61: 358-364. 
Catalyst Papers in Press are peer-reviewed, accepted articles that have not yet been edited or formatted, but may be cited by DOI. The final version may contain substantive or nonsubstantive changes.

doi: 10.5344/catalyst.2021.21007

7. Tardaguila JF, Martinez de Today J, Poni S and Diafo MP. 2010. Impact of early leaf removal on yield and fruit and wine composition of Vitis vinifera L. Graciano and Carignon. Am J Enol Vitic 63: 372-382.

8. Chellemi DO and Marios JJ. 1992. Influence of leaf removal, fungicide applications, and fruit maturity on incidence and severity of grape powdery mildew. Am J Enol Vitic 43: 53-57.

9. Delp CJ. 1954. Effect of temperature and humidity on the grape powdery mildew fugus. Phytopathology 44:615-626.

10. Thomas CS, Marios JJ and English JT. 1987. The effects of wind speed, temperature, and relative humidity on development of aerial mycelium and conidia of Botrytis cinerea on grape. Phytopathology 78: 260-265.

11. Austin CN and Wilcox WF. 2011. Effects of fruit-zone leaf removal, training systems, and irrigaiton on the development of grapevine powdery mildew. Am J Enol Vitic 62: 193-198.

12. Hed B and Centinari M. 2018. Hand and mechanical fruit-zone leaf removal at prebloom and fruitset was more effective in reducing crop yield than reducing bunch rot in 'Riseling' grapevines. HortTec 28: 296-303.

13. Komm BL and Moyer MM. 2015. Effect of early fruit-zone leaf removal on canopy development and fruit quality in Riesling and Sauvignon blanc. Am J Enol Vitic 66: 424-434.

14. Moyer MM, Newhouse JM and Grove GG. 2018. Adjusting product timing during the powdery mildew critical window to improve disease management. Catalyst 2:7-14.

15. Hickey CC and Wolf TK. 2019. Cabernet Sauvignon responses to prebloom and post-fruit set leaf removal in Virginia. Catalyst: Disc Prac 2: 24-34.

16. Poni S, Lorenzo X, Bernizzoni F, Civardi S and Intrieri C. 2006. Effects of early defoliation on shoot photosynthesis, yield components, and grape composition. Am J Enol Vitic 57:397-406.

17. Lee J and Skinkis PA. Oregon 'Pinot noir' grape anthocyanin enhancement by early leaf removal. Food Chem 139: 893-901.

18. Moyer M and O’Neal S (eds). 2014. Pest management strategic plan for Washington state wine grape production. Western IPM Center, United States Department of Agriculture. Online: https://ipmdata.ipmcenters.org/documents/pmsps/WA_WineGrape_PMSP_2014.pdf

19. Tarricone L, Faccia M, Masi G and Gambacorta G. 2020. The impact of early basal leaf removal at different sides of the canopy on Aglianico grape quality. Agric 10:630. 
Catalyst Papers in Press are peer-reviewed, accepted articles that have not yet been edited or formatted, but may be cited by DOI. The final version may contain substantive or nonsubstantive changes.

doi: $10.5344 /$ catalyst.2021.21007

20. Diago MP, Ayestarán B, Guadalupe Z, Poni S and Tardáguila J. 2012. Impact of prebloom and fruit set basal leaf removal on the flavonol and anthocyanin composition of Tempranillo grapes. Am J Enol Vitic 63: 367-376.

21. Poni S, Bernizzoni F, Civard S and Libelli N. 2009. Effects of pre-bloom leaf removal on growth of berry tissues and must composition in two red Vitis vinifera L. cultivars. Aus J Grape Wine Res 15:185-193.

22. Sabbatini P and Howell GS. 2010. Effects of early defoliation on yield, fruit composition, and harvest season cluster rot complex of grapevines. HortSci 45:1804-1808.

23. Smart R and Robinson M. 2003 Winegrape Canopy Ideotype In Sunlight Into Wine: A Handbook for Wine Grape Canopy Management. Winetitles, Adelaide, Australia. p. 28.

24. Gambetta JM, Holzapfel BP, Stoll M and Friedel M. 2021. Sunburn in grapes: A Review. Front Plant Sci 11: 604691.

25. Skinkis P. 2013. Determining impact of hand or machine leaf removal on fruit quality. Oregon Wine Research Institute. https://blogs.oregonstate.edu/owri/2013/12/10/determining-impactofmachine-leaf-removal-on-fruit-quality/

26. Iland PG, Ewart A, Sitters J, Markides A and Bruer N. 2000. Techniques for Chemical Analysis and Quality Monitoring During Winemaking. Patrick Iland Wine Promotion, Cambelltown, South Australia.

27. Hagerman AE and Butler LG. 1978. Protein precipitation method for the quantitative determination of tannins. J Agric Food Chem 26: 809-812.

28. Harbertson JF, Picciotto EA and Adams DO. 2003. Measurement of polymeric pigments in grape berry extracts and wines using a protein precipitation assay combined with bisulfite bleaching Am $\mathrm{J}$ Enol Vitic 54: 301-306.

29. Lorenz DH, Eichhorn KW, Bleiholder H, Klose R, Meier U and Weber E. 1994. Phaenologische Entwicklungsstadien der Weinrebe (Vitis vinifera L. ssp. vinifera). Codierung und Beschreibung nach der erweiterten BBCH-Skala. Vitic Enol Sci 49:66-70. 
Catalyst Papers in Press are peer-reviewed, accepted articles that have not yet been edited or formatted, but may be cited by DOI. The final version may contain substantive or nonsubstantive changes.

Table 1 Influence of year and leaf removal treatments on fruit set, berry size, and cluster weight on Vitis vinifera Cabernet Sauvignon and Merlot in Snipes Mountain American Viticulture Area in eastern Washington State, USA. Different letters denote significant differences among treatment means at $\alpha=0.05$ using Tukey's HSD.

\begin{tabular}{|c|c|c|c|c|c|}
\hline \multicolumn{6}{|c|}{ Cabernet Sauvignon } \\
\hline \multicolumn{2}{|l|}{ Effect } & $\%$ Fruit Set & $\begin{array}{l}\text { Berry diameter } \\
(\mathrm{mm})\end{array}$ & $\begin{array}{l}\text { Berry weight } \\
\text { (g) }\end{array}$ & $\begin{array}{c}\text { Cluster weight } \\
\text { (g) }\end{array}$ \\
\hline \multicolumn{6}{|l|}{ Year } \\
\hline & 2014 & $16.9 \% \mathrm{~b}$ & $10.37 \mathrm{a}$ & $0.97 \mathrm{~b}$ & $107.51 \mathrm{~b}$ \\
\hline & 2015 & $17.8 \% \mathrm{~b}$ & $10.29 \mathrm{a}$ & $0.83 \mathrm{c}$ & $102.78 \mathrm{~b}$ \\
\hline & 2016 & $25.3 \% \mathrm{a}$ & $12.31 \mathrm{~b}$ & $1.41 \mathrm{a}$ & $206.79 \mathrm{a}$ \\
\hline & $P$-value & $<0.0001$ & $<0.0001$ & $<0.0001$ & $<0.0001$ \\
\hline \multicolumn{6}{|c|}{ Leaf removal treatment } \\
\hline & Control & $22.5 \% \mathrm{ab}$ & $11.59 \mathrm{a}$ & $1.19 \mathrm{a}$ & $159.88 \mathrm{a}$ \\
\hline & Prebloom & $18.1 \% \mathrm{bc}$ & $11.26 \mathrm{a}$ & $1.10 \mathrm{ab}$ & $137.39 \mathrm{a}$ \\
\hline & Bloom & $14.6 \% \mathrm{c}$ & $9.82 \mathrm{~b}$ & $0.96 \mathrm{c}$ & $88.61 \mathrm{~b}$ \\
\hline & Postbloom & $20.9 \% \mathrm{ab}$ & $11.21 \mathrm{a}$ & $1.06 \mathrm{bc}$ & $170.12 \mathrm{a}$ \\
\hline & Mechanical & $23.7 \% \mathrm{a}$ & $11.11 \mathrm{a}$ & $1.03 \mathrm{bc}$ & $139.15 \mathrm{a}$ \\
\hline & P-value & 0.0002 & $<0.0001$ & $<0.0001$ & $<0.0001$ \\
\hline \multicolumn{6}{|c|}{ Treatment x Year } \\
\hline & P-value & 0.63 & 0.06 & 0.04 & 0.05 \\
\hline \multicolumn{6}{|c|}{ Merlot } \\
\hline Effect & & $\%$ Fruit Set & $\begin{array}{l}\text { Berry diameter } \\
(\mathrm{mm})\end{array}$ & $\begin{array}{l}\text { Berry weight } \\
\text { (g) }\end{array}$ & $\begin{array}{l}\text { Cluster weight } \\
\text { (g) }\end{array}$ \\
\hline \multicolumn{6}{|l|}{ Year } \\
\hline & 2014 & $27.2 \%$ & $12.1 \mathrm{a}$ & $1.53 \mathrm{a}$ & $158.18 \mathrm{~b}$ \\
\hline & 2015 & $25.1 \%$ & $11.2 \mathrm{~b}$ & $0.99 \mathrm{~b}$ & $114.29 \mathrm{c}$ \\
\hline & 2016 & $24.2 \%$ & $12.4 \mathrm{a}$ & $1.52 \mathrm{a}$ & $197.72 \mathrm{a}$ \\
\hline & P-value & 0.26 & $<0.0001$ & $<0.0001$ & $<0.0001$ \\
\hline \multicolumn{6}{|c|}{ Treatment } \\
\hline & Control & $28.8 \%$ & $11.89 \mathrm{ab}$ & $1.34 \mathrm{ab}$ & 156.21 \\
\hline & Prebloom & $25.1 \%$ & $12.05 \mathrm{a}$ & $1.38 \mathrm{ab}$ & 175.14 \\
\hline & Bloom & $23.6 \%$ & $11.16 \mathrm{~b}$ & $1.22 \mathrm{~b}$ & 131.46 \\
\hline & Postbloom & $24.1 \%$ & $12.32 \mathrm{a}$ & $1.32 \mathrm{ab}$ & 152.85 \\
\hline & Mechanical & $25.9 \%$ & $12.13 \mathrm{a}$ & $1.45 \mathrm{a}$ & 167.98 \\
\hline & $P$-value & 0.25 & 0.0013 & 0.04 & 0.11 \\
\hline \multicolumn{6}{|c|}{ Treatment x Year } \\
\hline & P-value & 0.83 & 0.86 & 0.68 & 0.34 \\
\hline
\end{tabular}


Catalyst Papers in Press are peer-reviewed, accepted articles that have not yet been edited or formatted, but may be cited by DOI. The final version may contain substantive or nonsubstantive changes.

doi: $10.5344 /$ catalyst.2021.21007

Table 2 Influence of year and leaf removal timing on fruit quality at harvest in Vitis vinifera Cabernet Sauvignon in the Snipes Mountain American Viticulture Area in eastern Washington State, USA. Different letters denote significant differences among treatment means at $\alpha=0.05$ using Tukey's HSD.

\begin{tabular}{|c|c|c|c|c|c|c|c|}
\hline Effect & $\begin{array}{l}\text { Soluble } \\
\text { solids } \\
\text { ( }{ }^{\circ} \text { Brix) }\end{array}$ & $\begin{array}{c}\text { TA } \\
(\mathrm{g} / \mathrm{L})\end{array}$ & $\mathrm{pH}^{*}$ & $\begin{array}{c}\text { IBMP } \\
\text { (ng / kg) }\end{array}$ & $\begin{array}{c}\text { Berry } \\
\text { Anthocyanin } \\
\text { (m/g fresh } \\
\text { weight) }\end{array}$ & $\begin{array}{c}\text { Skin } \\
\text { Tannins } \\
(\mathrm{mg} / \mathrm{g})\end{array}$ & $\begin{array}{l}\text { Skin } \\
\text { phenolics } \\
(\mathrm{mg} / \mathrm{g})\end{array}$ \\
\hline \multicolumn{8}{|l|}{ Year } \\
\hline 2014 & $27.03 \mathrm{a}$ & $4.57 \mathrm{c}$ & $3.87 \mathrm{a}$ & $5.53 \mathrm{~b}$ & $1.43 \mathrm{a}$ & $1.43 \mathrm{~b}$ & $3.02 \mathrm{~b}$ \\
\hline 2015 & $26.28 \mathrm{a}$ & $5.47 \mathrm{~b}$ & $3.67 \mathrm{~b}$ & $6.96 \mathrm{~b}$ & $1.08 \mathrm{~b}$ & $1.60 \mathrm{a}$ & $3.92 \mathrm{a}$ \\
\hline 2016 & $23.29 \mathrm{~b}$ & $7.40 \mathrm{a}$ & $3.64 \mathrm{~b}$ & $13.98 \mathrm{a}$ & $0.83 \mathrm{c}$ & $1.60 \mathrm{a}$ & $3.92 \mathrm{a}$ \\
\hline$P$-value & $<0.0001$ & $<0.0001$ & 0.0001 & $<0.0001$ & $<0.0001$ & 0.04 & 0.0002 \\
\hline \multicolumn{8}{|l|}{ Leaf removal treatment } \\
\hline Control & $25.50 \mathrm{ab}$ & 5.49 & 3.72 & 8.47 & 1.10 & $1.33 \mathrm{~b}$ & $3.12 \mathrm{~b}$ \\
\hline Prebloom & $25.63 \mathrm{ab}$ & 5.77 & 3.73 & 9.12 & 1.11 & $1.46 \mathrm{ab}$ & $3.30 \mathrm{~b}$ \\
\hline Bloom & $26.16 \mathrm{a}$ & 5.99 & 3.67 & 7.74 & 1.16 & $1.66 \mathrm{a}$ & $4.78 \mathrm{a}$ \\
\hline Postbloom & $25.53 \mathrm{ab}$ & 5.83 & 3.68 & 6.75 & 1.09 & $1.64 \mathrm{a}$ & $3.81 \mathrm{~b}$ \\
\hline Mechanical & $24.83 \mathrm{~b}$ & 5.98 & 3.70 & 12.03 & 1.10 & $1.63 \mathrm{a}$ & $3.07 \mathrm{~b}$ \\
\hline$P$-value & 0.05 & 0.18 & 0.42 & 0.20 & 0.96 & 0.006 & $<0.0001$ \\
\hline \multicolumn{8}{|l|}{ Treatment x Year } \\
\hline \begin{tabular}{l|l} 
& $P$ value
\end{tabular} & 0.73 & 0.86 & 0.04 & 0.63 & 0.22 & 0.53 & 0.11 \\
\hline
\end{tabular}

Table 3 Influence of year and leaf removal timing on fruit quality at harvest in Vitis vinifera Merlot. Different letters denote significant differences among treatment means at $\alpha=0.05$ using Tukey's HSD.

\begin{tabular}{|c|c|c|c|c|c|c|c|}
\hline Effect & $\begin{array}{l}\text { Soluble } \\
\text { solids } \\
\left({ }^{\circ} \text { Brix }\right)\end{array}$ & $\begin{array}{c}\text { TA } \\
(\mathrm{g} / \mathrm{L})\end{array}$ & $\mathrm{pH}^{*}$ & $\begin{array}{l}\text { IBMP } \\
\text { (ng / kg) }\end{array}$ & $\begin{array}{c}\text { Berry } \\
\text { Anthocyanin } \\
\text { (m/g fresh } \\
\text { weight) }\end{array}$ & $\begin{array}{c}\text { Skin } \\
\text { Tannins } \\
(\mathrm{mg} / \mathrm{g})\end{array}$ & $\begin{array}{c}\text { Skin } \\
\text { phenolics } \\
(\mathrm{mg} / \mathrm{g})\end{array}$ \\
\hline \multicolumn{8}{|l|}{ Year } \\
\hline 2014 & $25.51 \mathrm{a}$ & $3.86 \mathrm{~b}$ & $3.94 \mathrm{~b}$ & 11.12 & $1.02 \mathrm{a}$ & $1.15 \mathrm{a}$ & $2.84 \mathrm{~b}$ \\
\hline 2015 & $26.28 \mathrm{a}$ & $3.71 \mathrm{~b}$ & $4.04 \mathrm{a}$ & 16.86 & $1.15 \mathrm{a}$ & $1.07 \mathrm{a}$ & $3.31 \mathrm{a}$ \\
\hline 2016 & $22.99 \mathrm{~b}$ & $7.42 \mathrm{a}$ & $3.79 \mathrm{c}$ & 12.85 & $0.76 \mathrm{~b}$ & $0.78 \mathrm{~b}$ & $1.89 \mathrm{c}$ \\
\hline$P$-value & $<0.0001$ & $<0.0001$ & $<0.0001$ & 0.59 & $<0.0001$ & $<0.0001$ & $<0.0001$ \\
\hline \multicolumn{8}{|l|}{ Leaf removal treatment } \\
\hline Control & 24.50 & $5.13 \mathrm{ab}$ & 3.93 & 25.15 & 0.88 & 0.99 & 2.42 \\
\hline Prebloom & 25.49 & $5.38 \mathrm{a}$ & 3.94 & 11.85 & 1.01 & 1.01 & 2.74 \\
\hline Bloom & 25.15 & $4.92 \mathrm{ab}$ & 3.93 & 8.80 & 1.05 & 1.08 & 2.86 \\
\hline Postbloom & 29.97 & $4.68 \mathrm{~b}$ & 3.94 & 6.75 & 1.02 & 0.99 & 2.76 \\
\hline Mechanical & 24.49 & $4.86 \mathrm{ab}$ & 3.89 & 15.46 & 0.92 & 0.94 & 2.61 \\
\hline$P$-value & 0.15 & 0.02 & 0.48 & 0.12 & 0.14 & 0.74 & 0.31 \\
\hline \multicolumn{8}{|l|}{ Treatment $\mathrm{x}$ Year } \\
\hline P-value & 0.89 & 0.06 & 0.60 & 0.91 & 0.47 & 0.62 & 0.73 \\
\hline
\end{tabular}


Catalyst Papers in Press are peer-reviewed, accepted articles that have not yet been edited or formatted, but may be cited by DOI. The final version may contain substantive or nonsubstantive changes.

\begin{tabular}{|l|c|c|c|}
\hline \multicolumn{3}{|c|}{ Table 4 Vine phenological stage range in Vitis vinifera Cabernet Sauvignon and Merlot, and associated dates for } \\
fruit-zone leaf removal in this study. BBCH plant development stage as described by Lorenz et al. 1994. ${ }^{28}$ \\
\hline Timing of Fruit-zone Leaf Removal & Year & Cabernet Sauvignon & Merlot \\
\hline \multirow{3}{*}{ Prebloom - BBCH 55-57 } & 2014 & 20 May & 16 May \\
& 2015 & 19 May & 8 May \\
\hline & 2016 & 6 May & May \\
Bloom - BBCH 65 & 2014 & 9 June & 3 June \\
& 2015 & 28 May & 26 May \\
& 2016 & 16 May \\
\hline
\end{tabular}


Catalyst Papers in Press are peer-reviewed, accepted articles that have not yet been edited or formatted, but may be cited by DOI. The final version may contain substantive or nonsubstantive changes.

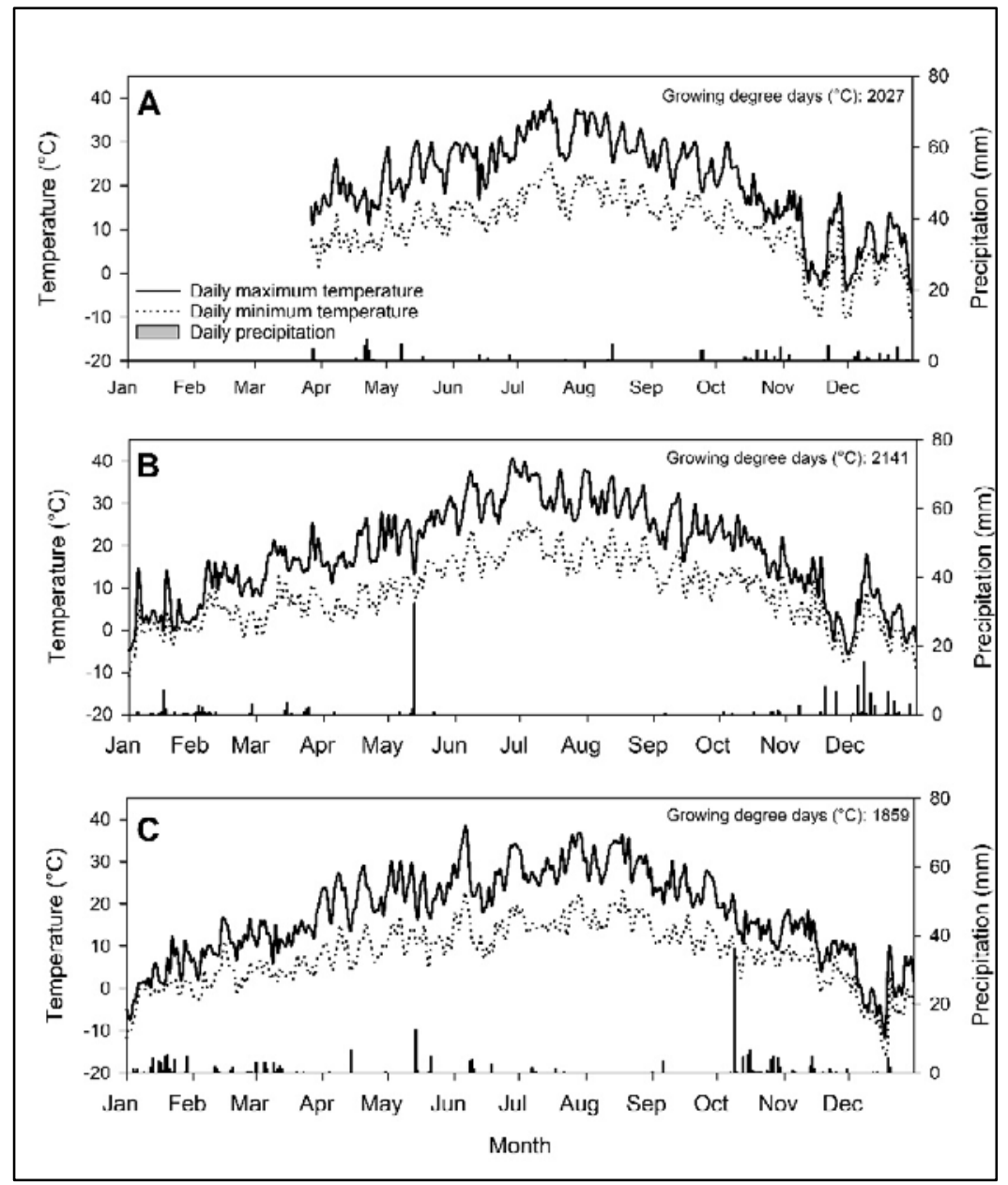

Figure 1 Daily maximum and minimum temperatures, and precipitation, for the commercial vineyard in 2014 (A), 2015 (B), and 2016 (C) located in the Snipes Mountain American Viticulture Area in eastern Washington State, USA. Washington State University AgWeatherNet 'Snipes Mountain' weather station was installed on 27 Mar 2014. (A) 2014 was considered a slightly-above-average temperature year, with consistent, low precipitation typical of the region. (B) 2015 was considered an exceptionally hot year, with a regional storm in late May which produced locally heavy rain. After that event, many of the remaining summer months (June, July, August, and September) did not have measurable precipitation. (C) 2016 was considered a relatively average year in terms of heat accumulation, with notable late-harvest rainfall for the region. 
Catalyst Papers in Press are peer-reviewed, accepted articles that have not yet been edited or formatted, but may be cited by DOI. The final version may contain substantive or nonsubstantive changes.

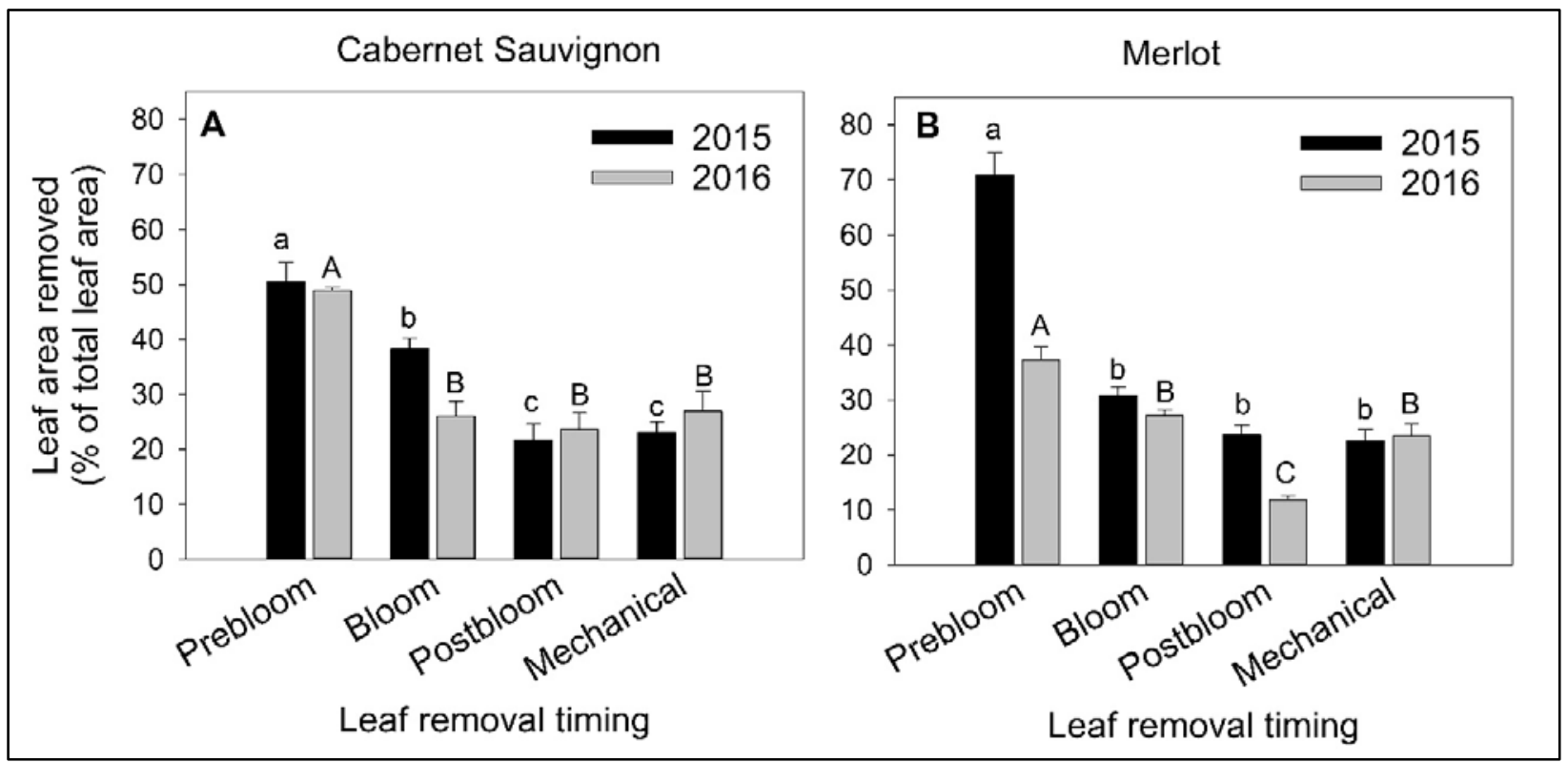

Figure 2 Total leaf area removed at the time of fruit-zone leaf removal indicated for (A) Vitis vinifera Cabernet Sauvignon, and (B) Vitis vinifera Merlot grown in the Snipes Mountain American Viticulture Area in eastern Washington State, USA. Error bars are standard error. Different letters denote significant differences among treatment means at $\alpha=0.05$ using Tukey's HSD; lower-case letters are means separation within a variety for 2015; upper-case letters are means separation within a variety for 2016. 
Catalyst Papers in Press are peer-reviewed, accepted articles that have not yet been edited or formatted, but may be cited by DOI. The final version may contain

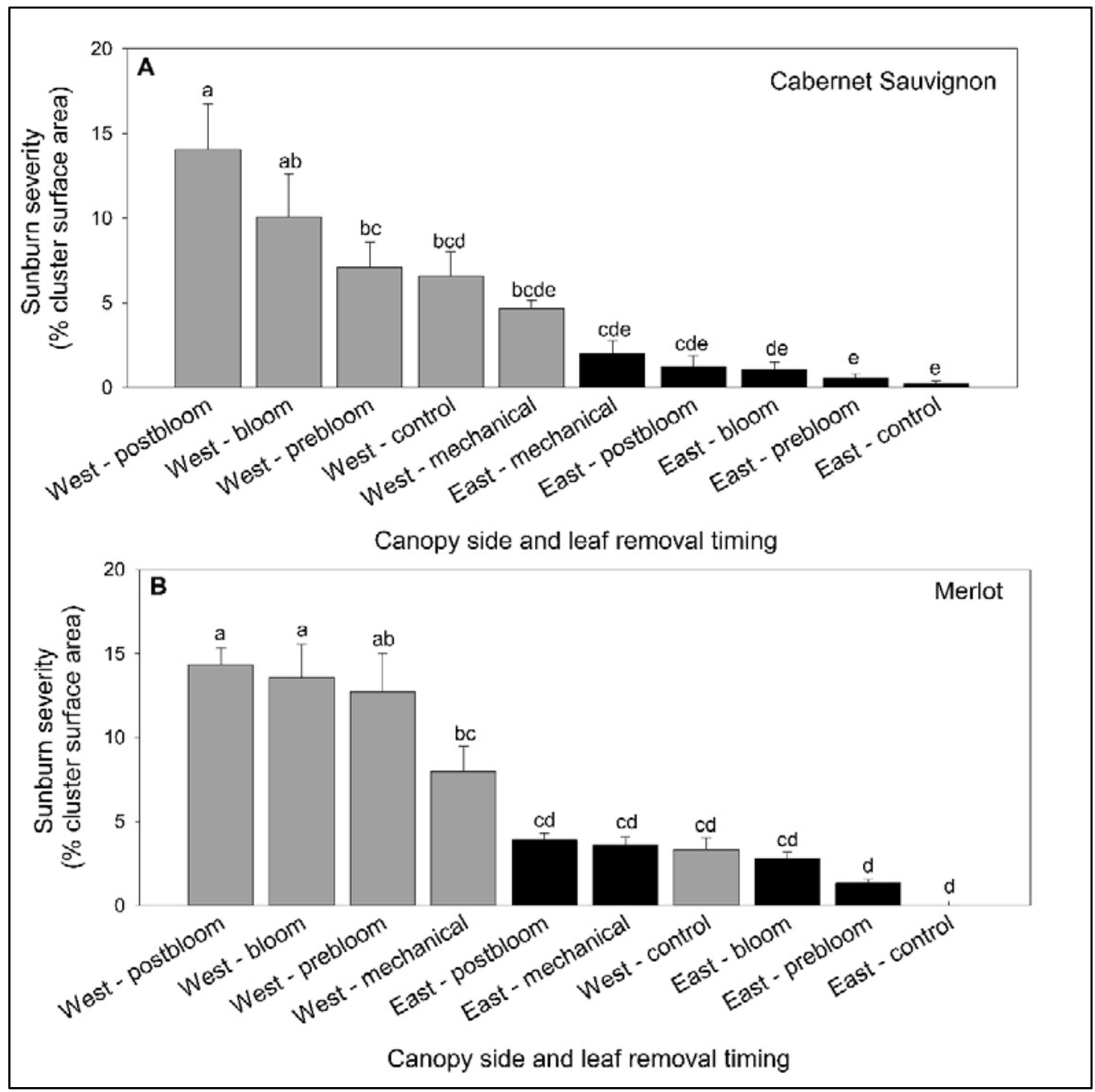

Figure 3 Sunburn severity on clusters, rated from the eastside and westside of the grapevine canopy for the specified timing of fruit-zone leaf removal in both (A) Vitis vinifera Cabernet Sauvignon, and (B) Vitis vinifera Merlot, grown at a commercial vineyard in the Snipes Mountain American Viticulture Area in eastern Washington State, USA. Average sunburn severity of clusters on the western sides of the vines are shaded grey, and average sunburn severity of clusters on the eastern sides of the vines are shaded black for easier viewing. Error bars are standard error. Different letters denote significant differences among treatment means at $\alpha=0.05$ using Tukey's HSD. 
Catalyst Papers in Press are peer-reviewed, accepted articles that have not yet been edited or formatted, but may be cited by DOI. The final version may contain substantive or nonsubstantive changes.

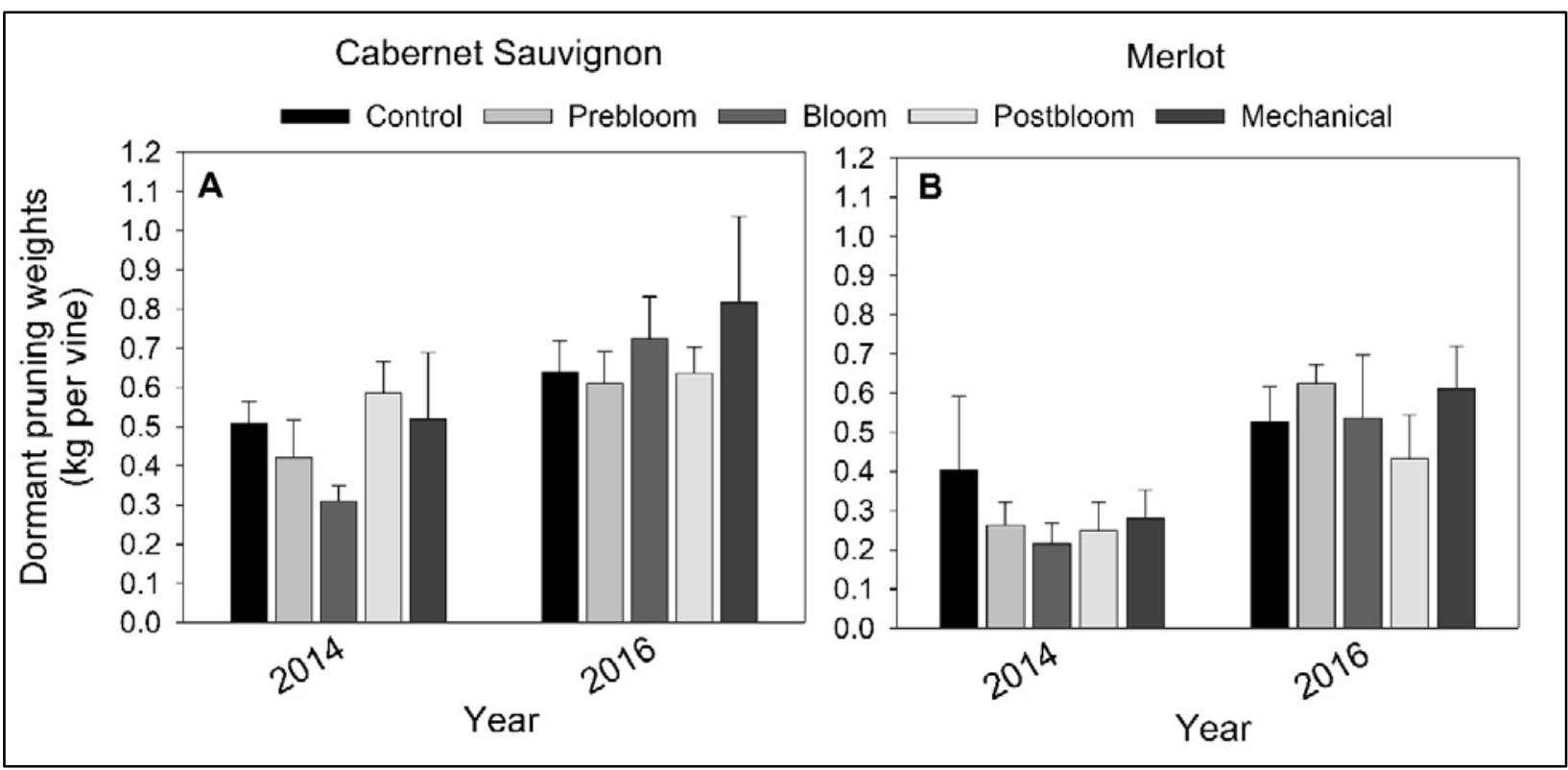

Figure 4 Dormant pruning weights in 2014 and 2016 of (A) Vitis vinifera Cabernet Sauvignon, and (B) Vitis vinifera Merlot vines that underwent fruit-zone leaf removal at different times. Vines were in a commercial vineyard in the Snipes Mountain American Viticulture Area in eastern Washington State, USA. Error bars are standard error. Leaf removal treatments did not statistically influence dormant pruning weights for either variety in the two years it was evaluated. 